\title{
Auxin protects Arabidopsis thaliana cell suspension cultures from programmed cell death induced by the cellulose biosynthesis inhibitors thaxtomin $A$ and isoxaben
}

\author{
Fatima Awwad ${ }^{1,2}$, Guillaume Bertrand ${ }^{3}$, Michel Grandbois ${ }^{3}$ and Nathalie Beaudoin ${ }^{1 *}$ (D)
}

\begin{abstract}
Background: Thaxtomin A (TA) is a natural cellulose biosynthesis inhibitor (CBI) synthesized by the potato common scab-causing pathogen Streptomyces scabies. Inhibition of cellulose synthesis by TA compromises cell wall organization and integrity, leading to the induction of an atypical program of cell death (PCD). These processes may facilitate S. scabies entry into plant tissues. To study the mechanisms that regulate the induction of cell death in response to inhibition of cellulose synthesis, we used Arabidopsis thaliana cell suspension cultures treated with two structurally different CBIs, TA and the herbicide isoxaben (IXB).

Results: The induction of cell death by TA and IXB was abrogated following pretreatment with the synthetic auxin 2,4-dichlorophenoxyacetic acid (2,4-D) and the natural auxin indole-3-acetic acid (IAA). The addition of auxin efflux inhibitors also inhibited the CBI-mediated induction of PCD. This effect may be due to intracellular accumulation of auxin. Auxin has a wide range of effects in plant cells, including a role in the control of cell wall composition and rigidity to facilitate cell elongation. Using Atomic Force Microscopy (AFM)-based force spectroscopy, we found that inhibition of cellulose synthesis by TA and IXB in suspension-cultured cells decreased cell wall stiffness to a level slightly different than that caused by auxin. However, the cell wall stiffness in cells pretreated with auxin prior to CBI treatment was equivalent to that of cells treated with auxin only.

Conclusions: Addition of auxin to Arabidopsis cell suspension cultures prevented the TA- and IXB-mediated induction of cell death. Cell survival was also stimulated by inhibition of polar auxin transport during CBI-treatment. Inhibition of cellulose synthesis perturbed cell wall mechanical properties of Arabidopsis cells. Auxin treatment alone or with CBI also decreased cell wall stiffness, showing that the mechanical properties of the cell wall perturbed by CBls were not restored by auxin. However, since auxin's effects on the cell wall stiffness apparently overrode those induced by CBls, we suggest that auxin may limit the impact of CBls by restoring its own transport and/or by stabilizing the plasma membrane - cell wall - cytoskeleton continuum.
\end{abstract}

Keywords: Auxin, Calcium, Cell wall, Isoxaben, Programmed cell death, Thaxtomin A

\footnotetext{
*Correspondence: nathalie.beaudoin@usherbrooke.ca

${ }^{1}$ Centre SĖVE, Département de biologie, Université de Sherbrooke,

Sherbrooke, Québec J1K 2R1, Canada

Full list of author information is available at the end of the article
}

(c) The Author(s). 2019 Open Access This article is distributed under the terms of the Creative Commons Attribution 4.0 International License (http://creativecommons.org/licenses/by/4.0/), which permits unrestricted use, distribution, and reproduction in any medium, provided you give appropriate credit to the original author(s) and the source, provide a link to the Creative Commons license, and indicate if changes were made. The Creative Commons Public Domain Dedication waiver (http://creativecommons.org/publicdomain/zero/1.0/) applies to the data made available in this article, unless otherwise stated. 


\section{Background}

The plant cell wall plays essential roles in plant growth and development and determines cell form and size by regulating processes such as cell elongation, adhesion and water movement. It also participates in intercellular communication and offers cellular protection against biotic and abiotic aggression [1,2]. The primary cell wall is a strong but dynamic structure that can be modified by enzymatic and non-enzymatic proteins to modulate its elasticity and extensibility in response to growth signals or environmental changes [3, 4].

Cellulose is the main structural constituent of the plant cell wall. This polysaccharide is made up of chains of $\beta-1$ 4 glucose subunits linked to each other by hydrogen bonds to form microfibrils, which are embedded in a gellike matrix comprising pectins, hemicellulose and protein $[3,5]$. Cellulose microfibrils are the strongest component of the cell wall [6]. One of the most recent conceptual models of the plant cell wall organization proposes that microfibrils form bundles by direct contacts between cellulose microfibrils and at load-bearing junctions where microfibrils intertwine with xyloglucan [4]. These interactions are necessary to increase cell wall mechanical resistance. Pectins, which bind the hydrophilic surface of cellulose, fill the space between microfibrils to regulate cell wall elasticity $[4,7]$. Pectins have also been implicated in maintaining and sensing cell wall integrity during salt stress $[8]$ and pathogen interactions $[9,10]$.

Cellulose biosynthesis is mediated by different cellulose synthase (CESA) proteins assembled in multiprotein complexes called cellulose synthesis complexes (CSCs), which can be seen as a rosette structure in the plasma membrane $[2,5,6,11]$. Pre-assembled CSCs are transported to the plasma membrane through the Golgi apparatus, the transGolgi network and ultimately into small compartments that associate with microtubules $[5,6]$. Disruption of cellulose biosynthesis as induced by cellulose biosynthesis inhibitors (CBIs) perturbs the function and organization of the cell wall, altering cell expansion and cell wall integrity [6].

Several plant pathogens can perturb cell wall synthesis or organization in order to colonize plant tissues. In particular, the potato common scab pathogen Streptomyces scabies (syn. scabiei) synthesizes during the infection process a phytotoxin called thaxtomin A (TA), which is a natural cellulose biosynthesis inhibitor (CBI) [12-16]. TA is the main pathogenicity determinant responsible for common scab symptoms, as treatment of potato tubers with TA induces scab-like symptoms [17-19] and inhibition of TA synthesis in normally pathogenic strains abolishes the formation of scab-like symptoms on infected tubers [20, 21]. It was proposed that the actinobacterium S. scabies would use TA to facilitate bacterial penetration of plant cell walls [15]. However, the specific action of TA on the cell wall organization and integrity is not known yet.
At the plant level, the effects of TA are very similar to those induced by the well-known CBI isoxaben (IXB). In Arabidopsis thaliana seedlings, TA causes a reduction of growth, root swelling, induction of ectopic lignification and defense-related gene expression [16, 22-26]. While IXB specifically targets CESA3 and CESA6 [27, 28], the specific molecular target of TA is unknown. However, it is most probably different from that of IXB, as mutants resistant to IXB are not resistant to TA [29]. Moreover, TA induces a pattern of ectopic lignification different than that induced by IXB, and changes in gene expression induced by TA are not entirely mimicked by IXB treatment $[22,26]$.

In Arabidopsis cell suspensions, inhibition of cellulose biosynthesis by IXB or TA triggers cellular hypertrophy and induces an atypical program of cell death (PCD) [30]. However, little is known on the regulation of this unusual PCD. It was shown that TA-induced PCD depends on a calcium influx and is abrogated by transcription and translation inhibitors [30, 31]. TA-induced PCD is not associated with $\mathrm{H}_{2} \mathrm{O}_{2}$ production and does not involve defense-related mitogen-activated protein kinase (MAPK) signaling [26, 30, 31]. Since TA is the main pathogenicity factor of potato common scab, reducing the impact of TA on plant cells stands out as a promising strategy to counter this disease. It was reported that resistance to common scab was increased by spraying potato plants with the synthetic auxin 2,4dichlorophenoxyacetic acid (2,4-D) at tuber induction, an effect that was attributed to decreased TA toxicity in tubers [32]. Similarly, TA inhibition of Arabidopsis seedling growth can be reversed by the synthetic auxin 2,4-D or the natural auxin indole-3-acetic acid (IAA) [32]. However, it is not clear how auxin treatment can reduce TA toxicity in tubers or seedlings.

In this work, we used Arabidopsis cell suspensions to study the mechanisms that regulate the induction of cell death in response to TA at the cellular level. We showed that synthetic and natural auxin pretreatment can protect cells from TA-induced cell death. This protection was not specific to the TA molecule itself; auxin pretreatment also abrogated cell death induced by IXB. Moreover, inhibitors of calcium influx and auxin efflux inhibitors decreased the induction of cell death by both CBIs. Auxin induces changes in cell wall composition and increases cell wall loosening, which facilitates cell elongation. Using AFM in force measurement mode, we found that TA or IXB treatment led to diminishing cell wall stiffness at a level significantly different than that observed after auxin treatment. However, the combination of auxin pretreatment followed by CBI addition reduced cell wall stiffness to a level equivalent to that observed after auxin treatment alone. We discuss how auxin may restrain the impact of inhibition of cellulose 
synthesis by stimulating rapid changes in the plasma membrane - cell wall interface.

\section{Results}

Increase in cytosolic calcium is necessary for CBI-induced cell death

A rapid and short calcium influx has been measured in Arabidopsis cells and seedlings in response to TA treatment $[31,33]$. Pretreatment of cell cultures with the calcium channel inhibitor lanthanum chloride $\left(\mathrm{LaCl}_{3}\right)$ inhibited TA-induced cell death, indicating that the increase in cytosolic calcium was required to activate the signaling cascade leading to the induction cell death by TA in Arabidopsis cells [31]. The inhibitor of cellulose synthesis IXB also activated a program of cell death very similar to that induced by TA, but the implication of calcium in IXB-induced cell death had never been investigated. To determine whether calcium influx was required for the IXB-induced cell death, we used different calcium transport inhibitors (Fig. 1); $\mathrm{LaCl}_{3}$, which inhibits extracellular calcium uptake, and ruthenium red (RR), which putatively blocks calcium release from intracellular stores and inhibits the mitochondrial calcium uniporter [34-36]. These inhibitors were added to Arabidopsis cell cultures $30 \mathrm{~min}$ before adding TA or IXB. As reported before [31], $\mathrm{LaCl}_{3}$ significantly reduced the percentage of cell death in TA-treated cells from $72 \%$ down to 56\% (Fig. 1a). The effect of $\mathrm{LaCl}_{3}$ was even more important in IXB-treated cells, with a reduction of cell death from $84 \%$ down to $19 \%$ (Fig. 1c). Pretreatment with RR also inhibited the induction of cell death mediated by both CBIs, decreasing cell death by $36 \%$ in TAtreated cells and by $54 \%$ for IXB treatment (Fig. $1 \mathrm{~b}$ and d). Both treatments also inhibited the typical cell bulging observed in response to $\mathrm{CBI}$ [30] and decreased the average cell size (Table 1; Additional file 1), indicating that these inhibitors may affect cell elongation.

\section{Auxin protects Arabidopsis cells from CBI-induced cell death}

Since 2,4-D has been proposed to reduce TA toxicity in Arabidopsis seedlings and potato tubers [32], we determined whether it could also protect from TA-induced cell death at the cellular level. Arabidopsis cell suspension cultures were pretreated for $30 \mathrm{~min}$ with the synthetic auxin 2,4-D prior to the induction of cell death with TA. Dead cells were counted periodically over a period of $72 \mathrm{~h}$. As shown in Fig. 2a, the percentage of dead cells $48 \mathrm{~h}$ after TA addition was $79 \%$ whereas cultures pretreated with 2,4-D before adding TA showed only $18 \%$ of dead cells (Fig. $2 \mathrm{~b}$ ). This significant inhibition of cell death may be specifically attributed to 2,4-D or may be a more general response to auxin. To answer this question, we pretreated cells with the natural auxin IAA or the synthetic auxin 1-naphtalenacetic acid (NAA)

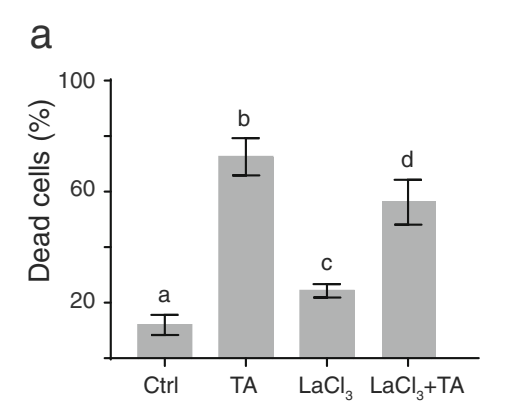

b
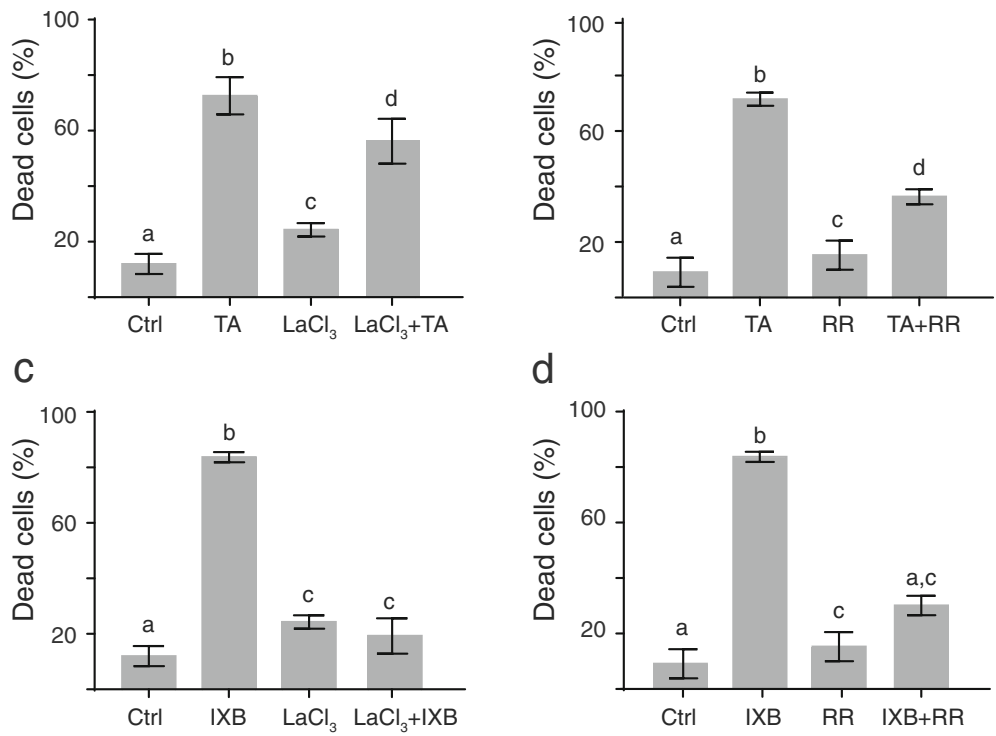

d

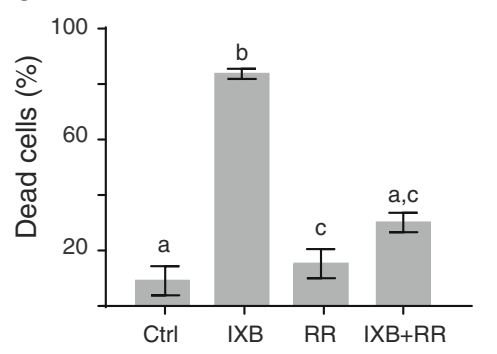

Fig. 1 Calcium influx is required for the CBI-induction of cell death. Percentage of dead cells in Arabidopsis suspension cells $48 \mathrm{~h}$ after the addition of calcium transport inhibitors. $\mathbf{a}$ and $\mathbf{c}$ Cells were treated with thaxtomin $\mathrm{A}(\mathrm{TA} ; 1 \mu \mathrm{M})$, isoxaben $(\mathrm{IXB} ; 1 \mu \mathrm{M})$ or lanthanum chloride $\left(\mathrm{LaCl}_{3} ; 500 \mu \mathrm{M}\right)$ alone, or pretreated with $\mathrm{LaCl}_{3}(500 \mu \mathrm{M}) 30$ min before adding TA or IXB. b and $\mathbf{d}$ Cells were treated with TA $(1 \mu \mathrm{M})$, IXB $(1 \mu \mathrm{M})$ or ruthenium red (RR; $50 \mathrm{nM}$ ) alone, or pretreated with $50 \mathrm{nM}$ of RR $30 \mathrm{~min}$ before adding TA or IXB. Ctrl = control cells treated with equal volume of methanol as treated samples. Each value is the mean of $n=15$ (100 cells each) \pm SD. Statistically different values (t-test followed by Holm-Šídák method, $p<0.05)$ are indicated by different letters 
Table 1 Distribution of cells according to cell length $(\mu \mathrm{m}) 48 \mathrm{~h}$ after treatment with cellulose biosynthesis inhibitors, inhibitors of calcium transport and auxins

\begin{tabular}{llll}
\hline Treatment & \multicolumn{3}{l}{ Percentage of cells according to cell length } \\
\cline { 2 - 4 } & $10-40 \mu \mathrm{m}$ & $40-60 \mu \mathrm{m}$ & $>60 \mu \mathrm{m}$ \\
\hline Control (Methanol) & $44.0 \pm 11.7$ & $33.4 \pm 2.4$ & $26.5 \pm 9.3$ \\
Thaxtomin A & $75.5 \pm 2.2^{*}$ & $22.6 \pm 0.2$ & $4.1 \pm 0.2^{*}$ \\
Isoxaben & $67.9 \pm 4.7^{*}$ & $27.1 \pm 1.5$ & $10.9 \pm 6.2^{*}$ \\
$\mathrm{LaCl}_{3}$ & $92.6 \pm 4.3^{*}$ & $4.7 \pm 1.8^{*}$ & $2.7 \pm 0.6^{*}$ \\
RR & $85.8 \pm 5.6^{*}$ & $12.8 \pm 2.7^{*}$ & $1.5 \pm 1.0^{*}$ \\
2,4-D & $89.6 \pm 6.3^{*}$ & $7.2 \pm 3.3^{*}$ & $3.2 \pm 2.8^{*}$ \\
IAA & $72.1 \pm 8.6^{*}$ & $17.5 \pm 5.7^{*}$ & $10.4 \pm 4.6^{*}$ \\
\hline
\end{tabular}

${ }^{a}$ Cells stained with trypan blue were visualized by light microscopy and photographed. Cell dimensions were measured using Fiji software [37] for 300 cells per condition. Results show the mean percentage of cells in each category of length from 3 replicates \pm SD. $\left(^{*}\right)$ indicates statistically significant difference with control in each category (t-test followed by Holm-Šídák method, $p<0.05$ )

before adding TA. As shown in Additional file 2, IAA pretreatment alone increased the percentage of cell death to $48 \%$ within $48 \mathrm{~h}$, but it significantly decreased the percentage of cell death induced by TA, with $49 \%$ of cell death in IAA-pretreated cells compared to $79 \%$ in TA only-treated cells. However, pretreatment of cell cultures with NAA at low concentration (1 and $10 \mu \mathrm{M})$ was not effective in protecting from cell death induced by TA. When we used higher concentrations $(30 \mu \mathrm{M}$; Additional file 2$)$, NAApretreatment alone increased cell death at a level similar to that induced by TA, making it impossible to determine whether NAA could effectively alter the response to TA.

Auxins may exert their protective effect directly against the TA molecule itself (e.g., competition, interaction) or may protect cells from TA's ability to inhibit cellulose synthesis or its downstream consequences. To discriminate between these possibilities, we repeated the previous experiments using a structurally different inhibitor of cellulose biosynthesis IXB, which also induced PCD in Arabidopsis cell cultures [30]. Arabidopsis cell suspension cultures were pretreated for $30 \mathrm{~min}$ with various concentrations of 2,4-D, IAA or NAA followed by IXB treatment. All auxin pretreatments at a concentration of $1 \mu \mathrm{M}$ were able to reduce significantly the percentage of cell death induced by IXB, but this reduction was of only $11 \%$ in $2,4-\mathrm{D}$ pretreated cells (Additional file 3 ). The protective effect of the natural auxin IAA against IXB is presented at Fig. 2b. Pretreatment with IAA prior to IXB addition reduced the percentage of cell death from $84 \%$ in IXB-treated cells down to $52 \%$ in IAA-pretreated cells $48 \mathrm{~h}$ after the addition of IXB.

\section{Inhibition of auxin efflux protects cells from CBI-induced cell death}

Decreased cellulose synthesis by TA and IXB significantly reduced cell elongation within $48 \mathrm{~h}$ in Arabidopsis

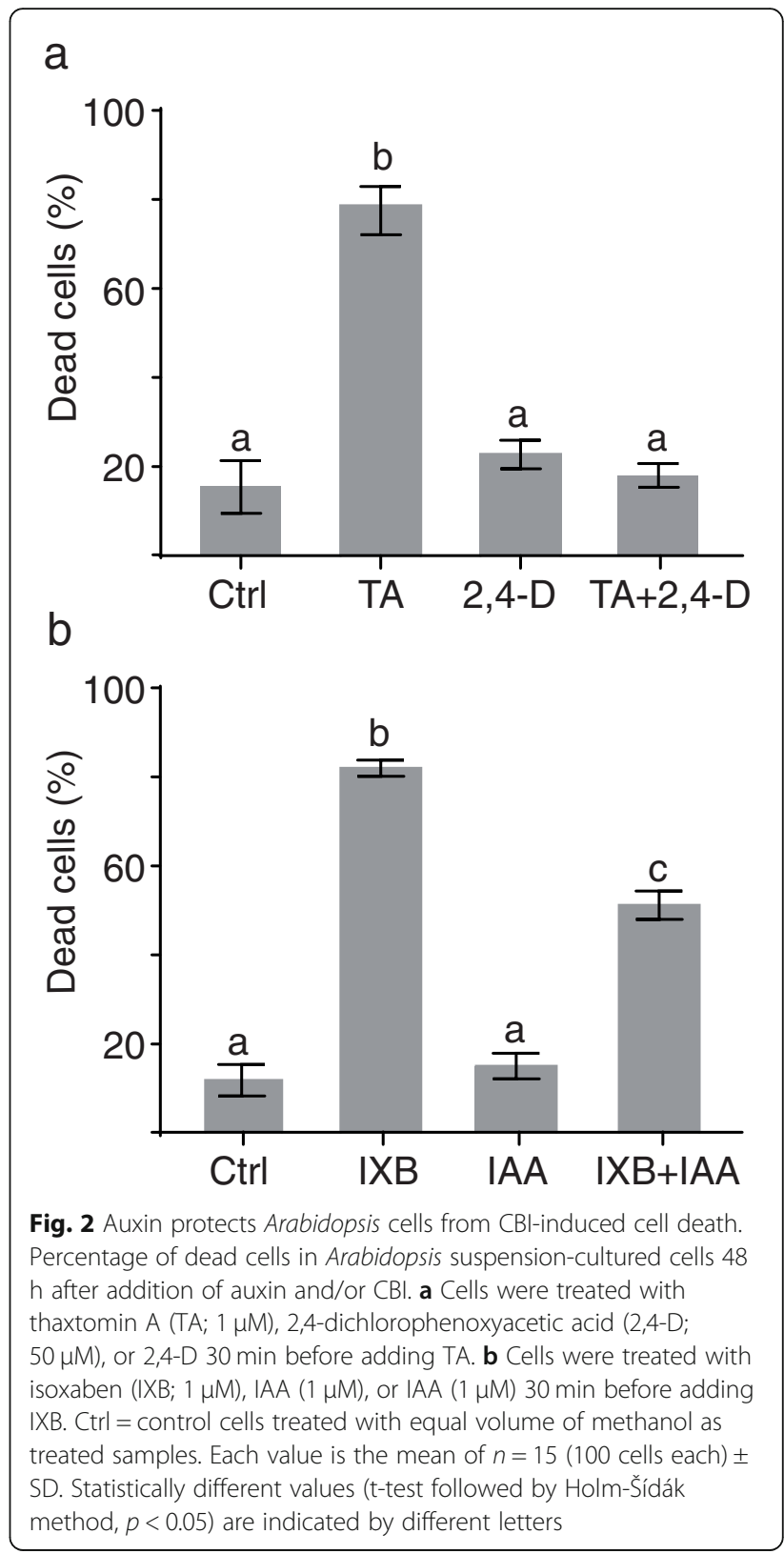

cell suspension cultures (Table 1). However, CBI induced a radial expansion (hypertrophy and bulging) of cells at the end of cell files in suspension-cultured cells ([30]; Additional file 1). Interestingly, hypertrophied cells remained alive longer than other cells in response to TA or IXB. This observation suggests the polarized accumulation of a compound or signal that would stimulate cell survival at the end of cell files. Auxin stands out as a good candidate as this hormone is transported in a directional and polarized fashion in plants as well as in tobacco BY-2 cell suspension cultures [35]. In light of our results with auxins, we hypothesized that the enhanced survival of hypertrophied cells may be associated with the polar transport and accumulation of auxin at the 
end of cell files. Accordingly, addition of exogenous auxin to cell cultures would increase the intracellular level of auxin and thus promote cell survival in most cells even after CBI-treatment.

To evaluate the importance of polar auxin transport in the induction of cell death by CBI, we treated cell suspensions with two different auxin efflux inhibitors, i.e., $N$-1-naphthylphthalamic acid (NPA) and triiodobenzoic acid (TIBA), and two auxin influx inhibitors, i.e., 3chloro-4-hydroxyphenylacetic acid (CHPAA) and 2naphthoxyacetic acid (2-NOA). Since NPA and TIBA also have other effects in plant cells, including perturbation of vesicle trafficking and cytoskeleton, we used a concentration for each chemical that did not alter the cytoskeleton [38-40]. NPA or TIBA was added to Arabidopsis cell suspensions $30 \mathrm{~min}$ prior to CBI-treatment. Dead cells were counted over a period of $48 \mathrm{~h}$. As shown in Fig. 3a, the percentage of dead cells in TA-treated cells was significantly decreased by pretreatement with NPA and TIBA from $87 \%$ down to 65 and $40 \%$ respectively. In contrast, pretreatment with auxin influx inhibitors, such CHPAA and 2-NOA, had no effect on TAinduced cell death. Again, this reduction in cell death was not specific to the TA molecule itself as it was observed in IXB-treated cell cultures as well. Cell cultures pretreated with NPA or TIBA before the addition of IXB had fewer dead cells (25 to 28\%) than IXB-treated cell cultures (Fig. 3b). This data shows that blocking auxin efflux using TIBA and NPA increases the survival rate of CBI-treated cells.

\section{$\mathrm{CBI}$ and auxin decrease cell wall stiffness and restrain cell elongation}

Inhibition of cellulose synthesis by TA and IXB in Arabidopsis cell cultures and seedlings induced the expression of genes involved in cell wall synthesis and ectopic accumulation of lignin [22, 26]. These responses were suggested to play a role in the reinforcement of the cell wall compromised by impaired cellulose synthesis. This could maintain cell wall mechanical properties and integrity required for cell survival, elongation and growth [22]. Auxin is also important for controlling cell wall composition and can induce cell wall loosening that is required for cell elongation. Since both CBI and auxin have an impact on the cell wall, it is possible that the protective effect of auxin against CBI is associated with their selective effects on the mechanical properties of the cell wall.

To determine the impact of TA and IXB as well as auxin on cell wall mechanical stiffness, we used Atomic Force Microscopy (AFM)-based force spectroscopy to measure mechanical properties expressed as the elastic modulus of the cell wall in living cells, as described previously [41]. Here, this technique allows a non-destructive analysis of

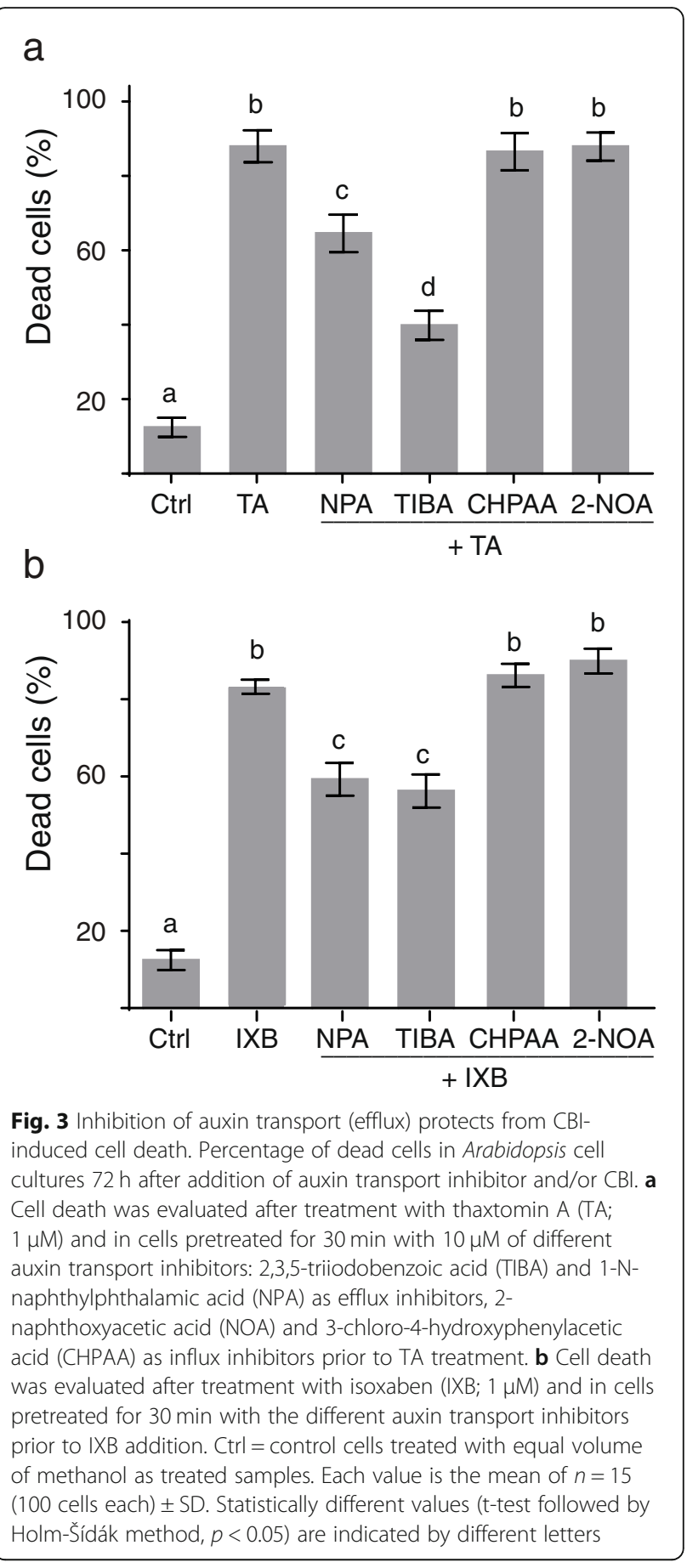

cells in order to assess the impact of CBI on the mechanical properties of the cell wall in living cells undergoing PCD. Young's modulus was extracted from force indentation curve recorded on cells treated for $24 \mathrm{~h}$ with each CBI, auxin or a combination of both (Fig. 4). We chose to perform AFM measurements on non plasmolysed cells in liquid medium as plasmolysis may change the cell response to $\mathrm{CBI}$ or auxin. In particular, plasmolysis can recapitulate some of the effects of IXB treatment $[42,43]$. 

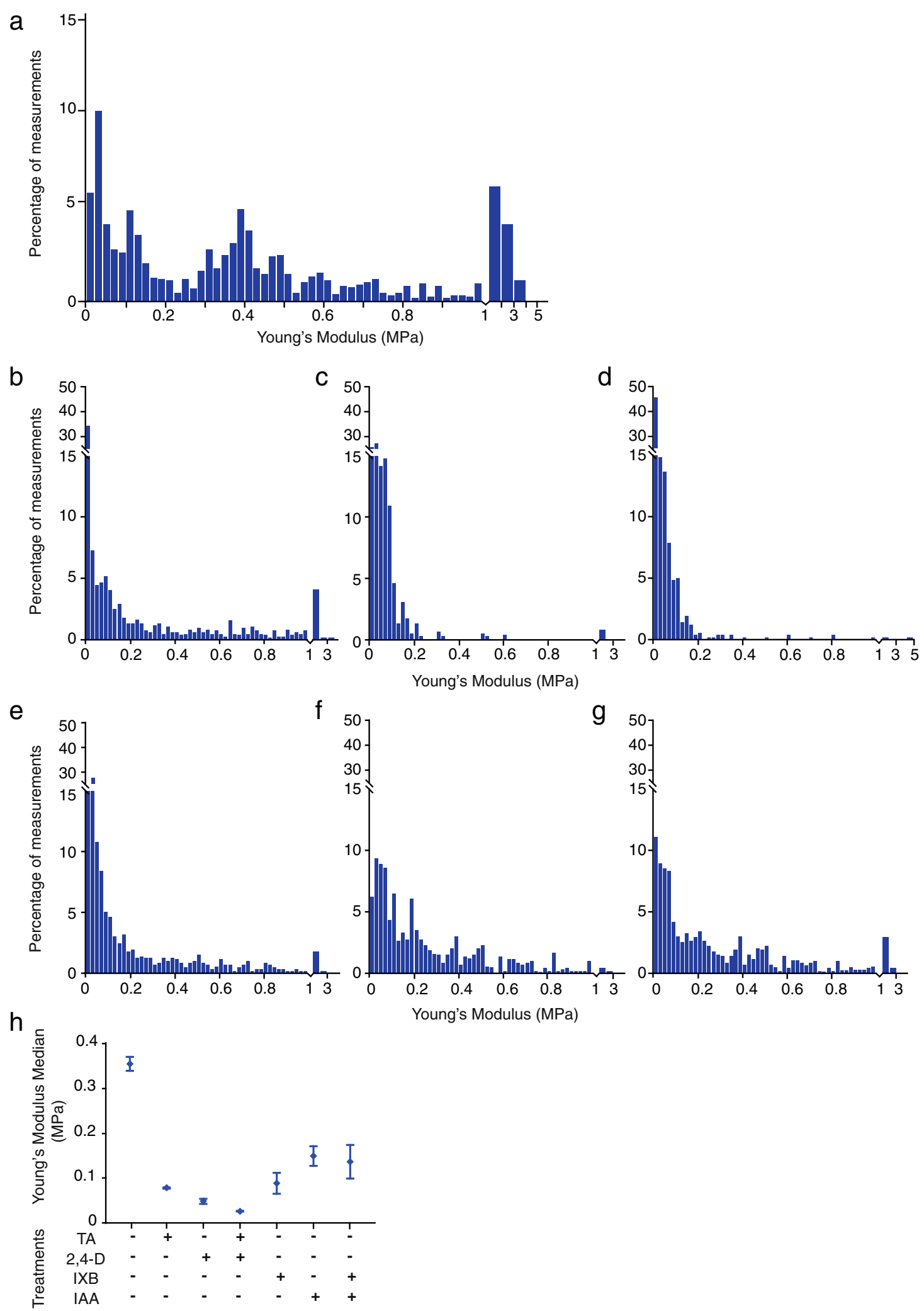

Fig. 4 (See legend on next page.) 
(See figure on previous page.)

Fig. 4 CBls and auxin decrease cell wall stiffness. Atomic force microscopy (AFM) was used to measure cell wall stiffness profiles of Arabidopsis suspension-cultured cells treated with: a methanol (control), b thaxtomin A (TA; $1 \mu \mathrm{M})$, c 2,4-dichlorophenoxyacetic acid (2,4-D; 50 $\mu \mathrm{M})$, d 2,4-D and TA, $\mathbf{e}$ isoxaben $(I X B ; 1 \mu M), \mathbf{f}|A A(1 \mu M), \mathbf{g}| A A$ and IXB for $24 \mathrm{~h}$. Force curves were recorded at the surface of 3 cells per condition in order to extract Young's modulus (MPa) values (see Material and Methods). Each histogram bar represents the relative proportion of Young's modulus values measured on the cell surface in each condition. Because of the low proportion of values measured above $1 \mathrm{MPa}$, a scale change was used after $1 \mathrm{MPa}$. $\mathbf{h}$ Average median values of Young's modulus were calculated for each condition from 3 different experiments ( 3 to 4 cells per experiment). Error bars represent SD

Plasmolysis and IXB modify the plasma membrane localization of PIN auxin efflux transporters, which can alter polar auxin transport [42]. Plasmolysis can also perturb the plasma membrane - cell wall - actin cytoskeleton continuum, as it was shown to alter actin remodelling and Golgi body motility [43]. Finally, we found that plasmolysis treatment slightly reduced CBI-induced PCD (Additional file 4), indicating that perturbation of the plasma membrane-cell wall interface by plasmolysis can alter the induction of PCD by CBI, the object of this study.

Arabidopsis cells treated with the indicated concentrations of auxin and CBI were compared to control cells originating from the same culture. Hence, any differences in the elastic modulus (Young's modulus) measured on the cell surface could be attributed to changes induced by the different CBI and auxin treatments. The histograms presented at Fig. 4 shows the distribution percentage of measured Young's modulus with values ranging from 0 to $5 \mathrm{MPa}$ for each treatment. We also calculated the average median of Young's modulus values for each treatment as summarized in Fig. 4h.

In control cells (Fig. 4a), Young's modulus values were distributed over a broad range, with close to $39 \%$ of values found below $0.2 \mathrm{MPa}$, and $50 \%$ found between 0.2 and $1 \mathrm{MPa}$. The average Young's modulus median value of cell walls in control cells was $0.355 \mathrm{MPa}$, which is comparable to results also obtained in Arabidopsis suspension cells by Radotić et al. (2012). In comparison to control cells, we observed a steep decrease in cell wall stiffness in cells treated with TA and IXB (Fig. 4b and e) with more than 67 and $68 \%$ respectively of the measurements below 0.2 MPa. Accordingly, the average Young's modulus median values (Fig. 4h) calculated for cell walls of TA- or IXB-treated cells, i.e., 0.078 and $0.089 \mathrm{MPa}$ respectively, were lower than the Young's modulus average median obtained in control cells $(0.355 \mathrm{MPa})$, demonstrating a significant drop in cell wall stiffness. This indicates that inhibition of cellulose synthesis drastically perturbed the mechanical properties of the cell wall.

Auxin's effect on cell wall mechanical properties was also evaluated. In 2,4-D-treated cells (Fig. 4c), more than $83 \%$ Young's modulus values were found below $0.1 \mathrm{MPa}$, with close to $94 \%$ found below $0.2 \mathrm{MPa}$, indicating a drastic reduction in cell wall stiffness compared to control cells. The combination of both 2,4-D and TA treatments decreased cell wall stiffness to a level comparable to that caused by 2,4-D (Fig. 4d), with close to $87 \%$ Young's modulus values found below $0.1 \mathrm{MPa}$ and up to $96 \%$ found below $0.2 \mathrm{MPa}$. As shown in Fig. $4 \mathrm{~h}$, the average Young's modulus median of cell walls from cells treated with 2,4-D alone $(0.049 \mathrm{MPa})$ or in combination with TA $(0.026 \mathrm{MPa})$ was lower than the average Young's modulus median value of TA-treated cells $(0.078 \mathrm{MPa})$. While the combined 2,4-D and TA treatments may contribute to the enhanced reduction in cell wall stiffness observed in comparison to cells treated with TA only, the distribution of Young's modulus values obtained after 2,4-D and TA combination closely resembled that of 2,4-D treated cells, suggesting that the effect of 2,4-D somehow superseded that of TA.

Cells treated with the natural auxin IAA alone also showed a decreased cell wall rigidity when compared to control cells, with $37 \%$ Young's modulus values distributed below $0.1 \mathrm{MPa}$ and $58 \%$ below $0.2 \mathrm{MPa}$ (Fig. 4f). The average Young's modulus median was of $0.149 \mathrm{MPa}$ (Fig. 4h). When IAA and IXB treatments were combined (Fig. 4g), the Young's modulus distribution of values was comparable to that observed after IAA treatment alone, with close to $40 \%$ Young's modulus values below 0.1 $\mathrm{MPa}$ and close to $52 \%$ below $0.2 \mathrm{MPa}$. In this case, average Young's modulus median value of the combined treatment was $0.137 \mathrm{MPa}$ (Fig. 4h), which is higher than the average Young's modulus median value $(0.089 \mathrm{MPa})$ obtained in cells treated with IXB only, suggesting that the reduction in cell wall stiffness induced by IXB was at least partially overridden by the effect of IAA.

Despite this drastic decrease in cell wall rigidity, we observed that Arabidopsis cell cultures treated with auxin or with CBIs exhibited a higher proportion of cells smaller than control cells (Table 1). In response to a 48 h-treatment with TA or IXB, 76 and $68 \%$ of cells respectively remained shorter than $40 \mu \mathrm{m}$ compared to $44 \%$ in control cells. This proportion was similar in IAA-treated cell cultures, with $72 \%$ of cells in the 10 $40 \mu \mathrm{m}$ category. Treatment with 2,4-D reduced cell elongation even more than CBIs or IAA, with over $89 \%$ cells in the 10 to $40 \mu \mathrm{m}$ category. Moreover, only 4 to $10 \%$ of TA- or IXB-treated cells and 3 to $10 \%$ in 2,4-D or IAA-treated cells were longer that $60 \mu \mathrm{m}$ compared to $26 \%$ in control cells. These results show that both 
CBIs and auxin decreased cell elongation in these experimental conditions.

\section{Discussion}

Inhibition of cellulose biosynthesis by TA and IXB in Arabidopsis cell cultures induced an atypical programmed cell death [30]. In most cases, defense-related PCD is preceded by a calcium influx that is associated with an oxidative burst characterized by the production of $\mathrm{H}_{2} \mathrm{O}_{2}$ [44] and the activation of a MAPK signaling pathway $[45,46]$. However, TA did not induce the production of $\mathrm{H}_{2} \mathrm{O}_{2}$ nor activated defense-associated MAPK pathways [30, 31], demonstrating that the induced PCD was different from the classical defense-related PCD. However, in Arabidopsis cells and seedlings, TA induced a rapid and short calcium influx essential for the induction of cell death and inhibition of growth [31, 33]. Rapid accumulation of cytosolic calcium can be detected in response to plant pathogens, specific elicitors and toxins but also in response to mechanical stimuli [47-49]. As reported for TA-induced PCD [31], the induction of cell death by IXB was inhibited by pharmacological inhibitors that block calcium influx $\left(\mathrm{LaCl}_{3}\right)$ and calcium release from internal stores (RR) (Fig. 1). These results provide evidence that changes in cytosolic calcium, which occurred after inhibition of cellulose synthesis, are early steps in the signalling cascade that leads to PCD, as observed in several types of PCDs [50].

TA is a natural biosynthesis inhibitor and the main pathogenicity factor of Streptomyces scabies, a filamentous actinobacterium causing the potato tuber disease common scab $[17,18]$. TA inhibits root growth in Arabidopsis, tomato and potato plants [33] and perturbs Arabidopsis seedling growth, an effect that can be reversed by the synthetic auxin 2,4-D or the natural auxin IAA [32]. In this work, we investigated the effect of auxin on TA-induced cell death at the cellular level using Arabidopsis cell suspension cultures. Pretreatment of Arabidopsis cell suspension cultures with 2,4-D or with the natural auxin IAA significantly increased cell survival of TA-treated cells when compared to control cells (Fig. 2a; Additional file 2). The synthetic auxin 2,4$D$ was more efficient than IAA at protecting from TAinduced cell death. This may be explained in part by the faster metabolic degradation of IAA compared to the metabolically stable 2,4-D [51]. These results demonstrate that both the natural auxin IAA and the synthetic auxin 2,4-D can significantly protect plant cells from the effects of TA. Synthetic and natural auxins were also very efficient in inhibiting cell death in response to IXB, another CBI structurally different than TA (Fig. 2b; Additional file 3$)$. In this case, even low levels $(1 \mu \mathrm{M})$ of the various auxins were able to significantly reduce cell death. Here, the most efficient auxin was NAA while 2, 4-D was the least efficient.
Overall, these results show that auxin protects cells against the consequences of inhibition of cellulose synthesis and not directly against the TA or IXB molecules. However, the level of protection against cell death varied depending on which auxinic compound and CBI was used. These variations may be due to differences in uptake, activity or rates of metabolic degradation for each auxinic molecule [51] or to the different modes of action of TA and IXB.

Pretreatment of Arabidopsis cell cultures with the auxin efflux transport inhibitors NPA and TIBA also increased cell survival in cells treated with CBI (Fig. 3). In contrast, auxin influx inhibitors CHPAA and 2-NOA had no not effect on CBI-induced cell death (Fig. 3). There are several examples which showed that blocking auxin efflux using NPA and TIBA can increase the accumulation of auxin in plant cells and plant tissues [35, 38, 51-56]. For instance, tobacco cells and Arabidopsis suspension cultures grown in the presence of radiolabelled auxins and the auxin efflux inhibitors TIBA and NPA had an increased accumulation of radiolabeled auxin $[38,51-53,55]$. The synchronization of cell division in tobacco cells, a process which depends on polar auxin transport, was also perturbed by NPA; this effect was attributed to increasing intracellular concentration of auxin due to reduced auxin efflux [35, 53]. In another experiment using citrus explants expressing an auxininducible GUS reporter gene, it was shown that polarized accumulation of auxin at the basal end of the stem cut was perturbed by NPA treatment, which induced an even distribution of auxin across the explant [56]. Finally, blocking auxin efflux with NPA in bean leaf petiole significantly enhanced accumulation of free IAA in leaf blades [54]. Based on these results, we suggest that inhibition of CBI-induced cell death by auxin efflux inhibitors is most likely due to the accumulation of endogenous auxin in cells. However, blocking auxin transport can also perturb auxin homeostasis within plants cells. To control intracellular auxin levels, various cellular mechanisms may be activated, including reduced auxin synthesis and conjugation or oxidation to inactive forms [57]. Whether these mechanisms are involved in the inhibition of CBI-induced cell death has not been investigated.

Other reports have also shown that auxin accumulation can inhibit PCD occurring during plant development or in response to stress. For example, the development of Norway spruce (Picea abies) somatic embryos involves the programmed elimination of suspensor and embryonal tube cells by PCD [58]. Inhibition of auxin transport using NPA inhibited PCD in suspensor and tube cells, suggesting that auxin accumulation in these cells perturbed PCD and embryo patterning [58]. Auxin has also been involved in the protection of stem cell niche from chilling stressinduced PCD in root tissues [59]. In normal conditions, auxin concentration in root stem cell niche is maximal in 
the quiescent center (QC) and follows a local gradient at the root tip. This auxin distribution allows division of root stem cells and inhibits division of columella stem cell daughters (CSCD), which are committed to differentiate. Chilling stress causes DNA damage that specifically induces PCD in CSCD whereas other cells from the root stem cell niche survive. Chilling stress also perturbs the distribution of auxin; low auxin levels contribute to PCD of CSCD, which in turn re-establish an auxin maximum in the stem cell niche to protect root stem cells from division and DNA-damage induced by chilling stress [59]. These examples and our results show that auxin plays a role in promoting cell survival during specific developmental stages or in response to various external conditions. However, how auxin can inhibit cell death in these cases has not yet been unravelled.

In the case of CBI-induced PCD, it is possible that auxin exerts its protective effect directly at the level of the cell wall. Auxin induces the expression of cell wallwall related genes and stimulates trafficking of vesicles containing new cell wall material $[60,61]$. Auxin can also regulate a variety of cell wall modifying enzymes including expansins and pectin methylesterase to control cell elongation [61, 62]. Regulation of cell elongation by auxin involves changes in the mechanical properties of the cell wall. This effect is explained by the "acid growth theory" which stipulates that extracellular acidification caused by auxin induces cell wall loosening to increase cell wall extensibility and cell expansion [61]. Auxin can also reduce cell wall stiffness through demethylesterification of the pectin homogalacturonan as observed in the shoot apex of Arabidopsis thaliana prior to organ outgrowth [63]. Hence, it is possible that auxin-mediated changes in the mechanical properties of the cell wall limit the impact of CBI.

We used AFM-based force spectroscopy to evaluate the effect of CBI and auxin on the mechanical properties of the cell wall of Arabidopsis suspension-cultured cells. This technique is non-destructive and can be used in living cells. The mechanical properties of the cell wall were expressed as the elastic modulus (Young's modulus) as described before [41]. As shown in Fig. 4, the average Young's modulus median value of the cell wall of control cells was around $0.355 \mathrm{MPa}$ while this value was down to 0.078 and 0.089 $\mathrm{MPa}$ in TA and IXB-treated cells respectively. This showed that CBI caused a drastic decrease in cell wall stiffness. This also demonstrated that the induced expression of cell wall genes in response to TA and IXB $[22,26]$ was not sufficient to compensate for changes caused by CBI. Similarly, auxin treatment also reduced cell wall stiffness; cells treated with 2,4-D or IAA had an average Young's modulus median values of 0.049 and $0.149 \mathrm{MPa}$ respectively. Interestingly, the pattern of distribution of Young's modulus values of cells treated with a combination of auxin and CBI was very similar to that of cells treated with auxin alone (Fig. 4). Changes induced by treatment with 2,4-D seemed to overcome those induced by TA (Fig. 4b-d). However, reduction in stiffness caused by IXB was partially overcome by pretreating cells with IAA.

Overall, these results indicate that CBI and auxin treatments all reduce cell wall stiffness compared to control cells. Moreover, this data shows that auxin treatment does not enhance cell survival by restoring the cell wall rigidity in CBI-treated cells. On the other side, the AFM data also suggests that the impacts of auxin treatment on the cell wall rigidity superseded at least partially those induced by CBI.

Increased cell wall extensibility by auxin is generally required to stimulate rapid cell elongation. However, we observed that Arabidopsis cell cultures treated with auxin contained a high proportion of cells smaller than control cells (Table 1), indicating that cell elongation was reduced by auxin despite the decreased cell wall stiffness. While auxin generally stimulates cell elongation, high auxin concentrations are inhibitory in root tissues $[60,64]$. It is possible that results obtained in dark-grown suspension cell cultures may partly mimic the effect observed in root tissues. Recently, it was shown that increasing endogenous or exogenous levels of auxin in root tissues induced a transient apoplast alkalinisation that would be responsible for inhibiting root elongation [65]. As observed in roots, addition of exogenous auxin reduced cell elongation in Arabidopsis suspension cultured-cells (Table 1). Similarly, inhibition of cellulose synthesis by TA and IXB also decreased cell elongation in Arabidopsis cells (Table 1) and was previously shown to impair root growth in seedlings $[22,25,33]$. Interestingly, a biphasic change in $\mathrm{pH}$ was measured after TA treatment of Arabidopsis cell suspensions, with a short acidification period that was followed by a large alkalinisation [31]. It is possible that changes in $\mathrm{pH}$ by auxin and $\mathrm{CBI}$ contributed to the inhibition of cell growth observed in this study. Overall, these results demonstrate that decreased cell wall stiffness does not necessarily correlates with stimulation of cell elongation.

Our results indicate that the mode of action of auxin in promoting cell survival in CBI-treated cells is clearly not limited to changes in cell wall mechanical properties. Several other possibilities will need to be explored to fully understand how auxin protects against CBI. For instance, it was shown that induction of cell wall defects by IXB perturbed the polarized localization of auxin PIN transporters, thus altering polarized auxin transport [66]. Cellulose synthesis is governed by microtubules, which control the orientation of CSC movement directing the orientation of cellulose microfibrils. In addition, microtubules appear to control PIN polarity in a cell specific manner [67]. The PIN auxin efflux carriers are localized in membrane microdomains associated with the cellulose-synthesizing 
CSCs. Therefore, perturbation of cellulose synthesis may compromise microtubule stability, altering PIN localization and inhibiting cell elongation [67]. Since auxin can itself enhance expression of PIN transporters and reestablish their polarized localization [68-71], auxin treatment can potentially restore auxin transport that was perturbed by cell wall defects. Restoration of PIN localization may stabilize their association with CSCs, which could in turn partially restore cell wall integrity by resuming cell wall synthesis. This hypothesis could also explain why the auxin-mediated decrease in cell wall stiffness seemed to override that induced by CBI.

Microtubules appear to work together with actin filaments to maintain auxin fluxes and establish auxin maxima. Therefore, changes in the configuration of the actin cytoskeleton may also play a role in the auxinmediated protection against CBI. The induction of cell wall defects by IXB can stimulate actin bundling [43] which is an early and essential event in PCD [72]. Auxin treatment can restore normal actin configuration [73, 74]. It was shown by Chang et al. (2015) that re-establishment of a normal actin configuration is involved in the auxinmediated protection against PCD induced in tobacco leaves by the proteinaceous elicitor harpin [75]. The protective effect of auxin would rely on modifications of the level of actin organization and its interaction with the plasma membrane [75]. Hence, it is possible that auxin prevents cell death induced by CBI by restoring a normal actin configuration that in turn would stabilize the plasma membrane - cell wall - cytoskeleton continuum.

\section{Conclusion}

We have shown that exogenous addition of synthetic and natural auxins to Arabidopsis cell cultures can inhibit PCD induced by two structurally different CBIs, TA and IXB. For both CBIs, initiation of cell death depended on an increase in cytosolic calcium originating from external and internal sources, which shows that calcium is involved at an early step in the signaling cascade leading to CBI-induced PCD. Addition of auxin efflux inhibitors (NPA and TIBA), which can increase the accumulation of auxin, was also shown to protect cells from CBI-induced PCD. These findings support work by others who showed that specific development- or defense-related PCDs can be inhibited by auxin. Auxin may also protect cells from CBI-induced cell death by inducing changes in the cell wall composition and organization to compensate for reduced cellulose synthesis. However, since cell wall stiffness evaluated by AFM-based force spectroscopy was found to be reduced both by CBI-inducers of PCD and auxin, we concluded that auxin-mediated protection against $\mathrm{CBI}$-induced PCD does not rely on reinforcement of the cell wall. We suggest that auxin may compensate for cell wall defects by stimulating rapid changes in the plasma membrane cell wall interface that could restore auxin transport and/or by re-establishing the plasma membrane - cell wall - cytoskeleton continuum important for cell survival. Further investigation will be required to evaluate these possibilities.

\section{Methods}

Plant material and treatments

Arabidopsis thaliana accession Landsberg erecta cell suspension cultures were graciously provided by Dr. Jean Rivoal (IRBV, Montréal, PQ, Canada). All chemicals were purchased from Sigma Aldrich unless otherwise indicated. Cell suspensions were grown in $45 \mathrm{~mL}$ Murashige and Skoog (MS) medium ( $\mathrm{pH}$ 5.7) supplemented with $\mathrm{B} 5$ vitamins and $1 \mathrm{mg} \mathrm{L}^{-1}$ 2,4-dichlorophenoxyacetic acid (2,4-D) in $125 \mathrm{~mL}$ Erlenmeyer flasks kept on a rotary shaker $(120 \mathrm{rpm})$ at $22^{\circ} \mathrm{C}$ in the dark. Arabidopsis cell cultures were subcultured every $7 \mathrm{~d}$ by diluting 15 $\mathrm{mL}$ cells into fresh medium. Treatments were performed using $10 \mathrm{~mL}$ log-phase cells 3 to $4 \mathrm{~d}$ after subculture. Thaxtomin A (TA) was prepared as described before [30]. TA (stock of $1 \mathrm{mM}$ ) and isoxaben (IXB; stock of $10 \mathrm{mM}$ ) were prepared in methanol and added at a final concentration of $1 \mu \mathrm{M}$. The same volume of methanol (less than $0.1 \%$ of final volume) was added to control cells. 2,4-D and IAA were dissolved in ethanol and 1naphtalenacetic acid (NAA) in water. These chemicals were added at the final concentration indicated in each experiment. Auxin transport inhibitors triiodobenzoic acid (TIBA), N-1-naphthylphthalamic acid (NPA), 2naphthoxyacetic acid (2-NOA) and 3-chloro-4-hydroxyphenylacetic acid (CHPAA) were dissolved in ethanol and added to cell cultures at a final concentration of $10 \mu \mathrm{M}$. Calcium inhibitors ruthenium red (RR) and lanthanum chloride $\left(\mathrm{LaCl}_{3}\right)$ were diluted in water and filtered. Cells were treated with a final concentration of 50 $\mathrm{nM}$ of $\mathrm{RR}$ and $500 \mu \mathrm{M}$ of $\mathrm{LaCl}_{3}$.

\section{Cell death assay}

Cell death was assessed using trypan blue staining as described before [30]. For microscopic evaluation, cells were incubated for $5 \mathrm{~min}$ in a fresh medium containing fluorescein diacetate (FDA) at a final concentration of $50 \mu \mathrm{M}$ and propidium iodide $(\mathrm{PI})$ at a final concentration of $2.78 \mu \mathrm{M}$. Images were taken with a Zeiss Imager Z1 microscope (Carl Zeiss Canada Ltd., Ontario, Canada) equipped with a monochromatic camera using AxioVision 4.8.2 version. Forty $\mu \mathrm{L}$ of cell culture were examined for living cells (FDA fluorescence) and dead cells (PI fluorescence). FDA was visualized with excitation wavelength of $488 \mathrm{~nm}$ and emission was collected between 510 and $530 \mathrm{~nm}$. PI was excited at $540 \mathrm{~nm}$ and emission was collected above 590 $\mathrm{nm}$ (590LP). For each condition, at least 500 cells in 
groups of 100 were counted. Each experiment was repeated at least three times.

\section{Measurement of cell dimensions}

Cell dimensions were determined using Fiji software [37] by measuring the length of 300 cells per condition from three independent experiments.

\section{Cell surface mechanics}

The elastic modulus (Young's modulus) of individual cells was quantified from force/tip-sample separation curves recorded using atomic force microscopy (AFM). Cells were pretreated for $24 \mathrm{~h}$ with different combinations of methanol (control), TA, IXB, 2,4-D or IAA using the concentrations indicated in each experiment. A $40 \mu \mathrm{l}$-aliquot of each culture was laid on a poly-L-lysine $(0.1 \mathrm{mg} \mathrm{mL}-1)$ coated slide cover slip for $5 \mathrm{~min}$ to allow adhesion. The cover slip was washed three times with culture medium before fixing it with a minute drop of vacuum grease in a small petri dish that was filled with $2 \mathrm{~mL}$ of culture medium prior to analysis. AFM analysis was conducted in contact mode as described before [41]. Briefly, AFM studies were performed with a JPK instrument NanoWizard ${ }^{\circ}$ 4. V.6 (Berlin, Germany) mounted on top of an inverted Zeiss imager Z1 microscope (Carl Zeiss Canada Ltd., Ontario, Canada). MLCT cantilevers A with a nominal spring constant of $0.07 \mathrm{~N} / \mathrm{m}$ were used (Bruker AFM probes, California, USA). For this cantilever we typically obtain a spring constant ranging from 0.05 to $0.11 \mathrm{~N} / \mathrm{m}$, using the thermal noise technique [76]. The Young's modulus was calculated using the Hertz model adapted for a four-sided pyramid indenter, built-in the JPK analysis software. The Young's modulus of the glass cover slip was considered infinitely rigid when compared to that of the measured cells. All studies were carried at room temperature. Force-curves were recorded at five different arbitrary locations in a $5 \mu \mathrm{m}$ radius over the cell surface leading to five batches of 30 to 50 points per cell. We used 3 to 4 cells per experiment. Each experiment was repeated 3 times.

\section{Statistics}

Statistical analysis was performed with GraphPad Prism 7. For cell death assay and measurements, cells were counted in groups of 100 and the mean was calculated from 3 to 15 replicates. Each experiment was repeated at least three times. Data was analyzed using t-test followed by Holm-Šídák method with alpha = 0.05 . Results were considered statistically different when $p$-value was $<0.05$.

\section{Supplementary information}

Supplementary information accompanies this paper at https://doi.org/10. 1186/s12870-019-2130-2.

Additional file 1: Figure S1. Visualization of cell death in Arabidopsis suspension-cultured cells $48 \mathrm{~h}$ after the addition of cellulose biosynthesis inhibitor $(\mathrm{CBI})$, lanthanum chloride $\left(\mathrm{LaCl}_{3}\right)$, ruthenium red $(\mathrm{RR})$, or $\mathrm{CBI}$ with auxin using epifluorescence microscopy (left) or light microscopy (right). Treatments: a) Control (methanol); b) Thaxtomin A (TA: $1 \mu \mathrm{M})$; c) Isoxaben (IXB: $1 \mu \mathrm{M})$; d) $\mathrm{LaCl}_{3}(500 \mu \mathrm{M})$; e) RR (50 nM); f) TA $(1 \mu \mathrm{M})+2,4$-dichlorophenoxyacetic acid $(2,4-D$ : $50 \mu \mathrm{M}) ; \mathbf{g})$ IXB $(1 \mu \mathrm{M})+$ IAA $(1 \mu \mathrm{M})$. Left panels: Cells were stained with propidium iodine $(\mathrm{PI})$ and fluorescein diacetate (FDA) to detect dead (red) and living cells (green). Right panels: Cells were stained with trypan blue to detect dead cells (black). Images were taken with upright microscope Zeiss Z1 imager. Scale $=100 \mu \mathrm{m}$.

Additional file 2: Figure S2. Auxin increases cell survival in thaxtomin A-treated cells. Percentage of cell death in Arabidopsis suspensioncultured cells at the indicate time after treatment with: 2,4-dichlorophenoxyacetic acid (2,4-D: $50 \mu \mathrm{M})$, thaxtomin A (TA: $1 \mu \mathrm{M})$, indole-acetic acid (IAA: $30 \mu \mathrm{M}), 1$-naphthaleneacetic acid (NAA; $30 \mu \mathrm{M})$ or combined treatments of TA with either 2,4-D, IAA or NAA. Each time point represents the average value of three different experiments including 500 cells each Error bars indicate SD. Statistically different values (t-test followed by Holm-Šídák method, $p<0.05$ ) are indicated by a different letter within each time point

Additional file 3: Figure S3. Auxin increases cell survival in isoxabentreated cells. Percentage of cell death in Arabidopsis suspension-cultured cells at the indicate time after treatment with: 2,4-dichlorophenoxyacetic acid (2,4-D: $1 \mu \mathrm{M})$, isoxaben (IXB: $1 \mu \mathrm{M})$, indole-acetic acid (IAA: $1 \mu \mathrm{M})$, 1naphthaleneacetic acid (NAA; $1 \mu \mathrm{M}$ ) or combined treatments of IXB with either 2,4-D, IAA or NAA. Each time point represents the average value of three different experiments including 500 cells each. Error bars indicate SD. Statistically different values (t-test followed by Holm-Šídák method, $p<0.05)$ are indicated by a different letter within each time point.

Additional file 4: Table S1. Thaxtomin A-induced cell death in plasmolysed cells.

\section{Abbreviations}

2,4-D: 2,4-Dichlorophenoxyacetic acid; AFM: Atomic Force Microscopy; CBI: Cellulose Biosynthesis Inhibitor; CESA: Cellulose Synthase; CSC: Cellulose Synthesis Complex; CTRL: Control; IAA: Indole-3-Acetic Acid; IXB: Isoxaben; PCD: Programmed Cell Death; TA: Thaxtomin A

\section{Acknowledgments}

Not applicable.

\section{Authors' contributions}

FA and NB conceived and designed most of the experiments. FA and MG designed the AFM experiments. FA performed most of the experiments. FA and GB carried out the AFM experiments. FA, GB and MG performed AFM data analysis and interpretation. FA and NB analyzed the remaining data and wrote the manuscript. All authors read and approved the manuscript.

\section{Funding}

This work was supported by the National Sciences and Engineering Council of Canada (NSERC) and the Faculté des Sciences of Université de Sherbrooke to $\mathrm{N}$. Beaudoin. The funders were not involved in the experimental design of the study, data collection, analysis and interpretation, and in writing the manuscript.

\section{Availability of data and materials}

The datasets used and/or analysed during the current study are available from the corresponding author on reasonable request.

Ethics approval and consent to participate Not applicable.

Consent for publication

Not applicable. 


\section{Competing interests}

The authors declare that they have no competing interests.

\section{Author details}

${ }^{1}$ Centre SĖVE, Département de biologie, Université de Sherbrooke, Sherbrooke, Québec J1K 2R1, Canada. 'Present address: Groupe de Recherche en Biologie végétale, Département de chimie, biochimie et physique, Université du Québec à Trois-Rivières, Trois-Rivières, Québec G9A 5 H7, Canada. ${ }^{3}$ Institut de Pharmacologie de Sherbrooke, Département de pharmacologie et physiologie, Université de Sherbrooke, Sherbrooke, Québec J1H 5N4, Canada.

Received: 17 June 2019 Accepted: 11 November 2019 Published online: 21 November 2019

\section{References}

1. Cosgrove DJ. Growth of the plant cell wall. Nat Rev Mol Cell Biol. 2005: 6:850-61

2. Keegstra K. Plant cell walls. Plant Physiol. 2010;154(2):483-6.

3. Cosgrove DJ. Plant cell wall extensibility: connecting plant cell growth with cell wall structure, mechanics, and the action of wall-modifying enzymes. $J$ Exp Bot. 2016:67:463-76

4. Cosgrove DJ. Diffuse growth of plant cell walls. Plant Physiol. 2018;176:16-27.

5. McFarlane HE, Döring A, Persson S. The cell biology of cellulose synthesis. Annu Rev Plant Biol. 2014;65:69-94.

6. Tateno M, Brabham C, DeBolt S. Cellulose biosynthesis inhibitors multifunctional toolbox. J Exp Bot. 2016;67:533-42.

7. Levesque-Tremblay G, Muller K, Mansfield SD, Haughn GW. Highly methyl esterified seeds is a pectin methyl esterase involved in embryo development. Plant Physiol. 2015;167:725-37.

8. Feng W, Kita D, Peaucelle A, Cartwright HN, Doan V, Duan Q, et al. The FERONIA receptor kinase maintains cell-wall integrity during salt stress through $\mathrm{Ca}^{2+}$ signaling. Curr Biol. 2018;28:666-75.e5.

9. Bethke G, Thao A, Xiong G, Li B, Soltis NE, Hatsugai N, et al. Pectin biosynthesis is critical for cell wall integrity and immunity in Arabidopsis thaliana. Plant Cell. 2016;28:537-56.

10. Lionetti V, Fabri E, De Caroli M, Hansen AR, Willats WG, Piro G, et al. Three pectin methylesterase inhibitors protect cell wall integrity for Arabidopsis immunity to Botrytis. Plant Physiol. 2017;173:1844-63.

11. Brabham C, Debolt S. Chemical genetics to examine cellulose biosynthesis. Front Plant Sci. 2012;3:309.

12. Beaulieu C, Goyer C, Beaudoin N. Interaction between pathogenic streptomycetes and plants: the role of thaxtomins. In: Barka EA, Clément C, editors. Plant-Microbe Interactions: Research Signpost; 2008:117-133.

13. Braun S, Gevens A, Charkowski A, Allen C, Jansky S. Potato common scab: a review of the causal pathogens, management practices, varietal resistance screening methods, and host resistance. Am J Potato Res. 2017;94:283-96.

14. King RR, Lawrence $\mathrm{CH}$, Clark MC. Correlation of phytotoxin production with pathogenicity of Streptomyces scabies isolates from scab infected potato tubers. Am Potato J. 1991;68:675-80.

15. Loria R, Bignell DR, Moll S, Huguet-Tapia JC, Joshi MV, Johnson EG, et al. Thaxtomin biosynthesis: the path to plant pathogenicity in the genus Streptomyces. Antonie Van Leeuwenhoek. 2008;94:3-10.

16. Scheible WR, Fry B, Kochevenko A, Schindelasch D, Zimmerli L, Somerville S, et al. An Arabidopsis mutant resistant to thaxtomin a, a cellulose synthesis inhibitor from Streptomyces species. Plant Cell. 2003;15:1781-94.

17. King RR, Lawrence $\mathrm{CH}$, Calhoun LA. Chemistry of phytotoxins associated with Streptomyces scabies, the causal organism of potato common scab. J Agric Food Chem. 1992;40:834-7.

18. Lawrence $\mathrm{CH}$, Clark MC, King RR. Induction of common scab symptoms in aseptically cultured potato tubers by the vivotoxin, thaxtomin. Phytopathology. 1990;80:606-8.

19. Francis IM, Jourdan S, Fanara S, Loria R, Rigali S. The cellobiose sensor CebR is the gatekeeper of Streptomyces scabies pathogenicity. MBio. 2015;6(2): e02018.

20. Goyer C, Vachon J, Beaulieu C. Pathogenicity of Streptomyces scabies mutants altered in thaxtomin a production. Phytopathology. 1998;88:442-5.

21. Healy FG, Wach M, Krasnoff SB, Gibson DM, Loria R. The txtAB genes of the plant pathogen Streptomyces acidiscabies encode a peptide synthetase required for phytotoxin thaxtomin a production and pathogenicity. Mol Microbiol. 2000;38:794-804.
22. Bischoff V, Cookson SJ, Wu S, Scheible WR. Thaxtomin a affects CESAcomplex density, expression of cell wall genes, cell wall composition, and causes ectopic lignification in Arabidopsis thaliana seedlings. J Exp Bot. 2009;60:955-65.

23. Caño-Delgado A, Penfield S, Smith C, Catley M, Bevan M. Reduced cellulose synthesis invokes lignification and defense responses in Arabidopsis thaliana. Plant J. 2003;34:351-62.

24. Ellis C, Karafyllidis I, Wasternack C, Turner JG. The Arabidopsis mutant cev1 links cell wall signaling to jasmonate and ethylene responses. Plant Cell. 2002;14:1557-66.

25. Tsang DL, Edmond C, Harrington JL, Nuhse TS. Cell wall integrity controls root elongation via a general 1-aminocyclopropane-1-carboxylic acid-dependent, ethylene-independent pathway. Plant Physiol. 2011;156:596-604.

26. Duval I, Beaudoin N. Transcriptional profiling in response to inhibition of cellulose synthesis by thaxtomin a and isoxaben in Arabidopsis thaliana suspension cells. Plant Cell Rep. 2009;28:811-30.

27. Desprez T, Vernhettes S, Fagard M, Refrégier G, Desnos T, Aletti E, et al. Resistance against herbicide isoxaben and cellulose deficiency caused by distinct mutations in same cellulose synthase isoform CESA6. Plant Physiol. 2002;128:482-90.

28. Scheible WR, Eshed R, Richmond T, Delmer D, Somerville C. Modifications of cellulose synthase confer resistance to isoxaben and thiazolidinone herbicides in Arabidopsis Ixr1 mutants. Proc Natl Acad Sci U S A. 2001;98: 10079-84

29. Tegg RS, Shabala SN, Cuin TA, Davies NW, Wilson CR. Enhanced resistance to the cellulose biosynthetic inhibitors, thaxtomin a and isoxaben in Arabidopsis thaliana mutants, also provides specific co-resistance to the auxin transport inhibitor, 1-NPA. BMC Plant Biol. 2013:13:76.

30. Duval I, Brochu V, Simard M, Beaulieu C, Beaudoin N. Thaxtomin a induces programmed cell death in Arabidopsis thaliana suspension-cultured cells. Planta. 2005;222:820-31.

31. Errakhi $R$, Dauphin A, Meimoun $P$, Lehner A, Reboutier D, Vatsa $P$, et al. An early $\mathrm{Ca}^{2+}$ influx is a prerequisite to thaxtomin A-induced cell death in Arabidopsis thaliana cells. J Exp Bot. 2008:59:4259-70.

32. Tegg RS, Gill WM, Thompson HK, Davies NW, Ross JJ, Wilson CR. Auxininduced resistance to common scab disease of potato linked to inhibition of thaxtomin a toxicity. Plant Dis. 2008;92:1321-8.

33. Tegg RS, Melian L, Wilson CR, Shabala S. Plant cell growth and ion flux responses to the streptomycete phytotoxin thaxtomin a: calcium and hydrogen flux patterns revealed by the non-invasive MIFE technique. Plant Cell Physiol. 2005;46:638-48.

34. Choi WG, Toyota M, Kim SH, Hilleary R, Gilroy S. Salt stress-induced Ca ${ }^{2+}$ waves are associated with rapid, long-distance root-to-shoot signaling in plants. Proc Natl Acad Sci U S A. 2014;111:6497-502.

35. Maisch J, Nick P. Actin is involved in auxin-dependent patterning. Plant Physiol. 2007;143:1695-704.

36. Kacprzyk J, Brogan NP, Daly CT, Doyle SM, Diamond M, Molony EM, McCabe PF. The retraction of the protoplast during PCD is an active, and interruptible, calcium-flux driven process. Plant Sci. 2017;260:50-9.

37. Schindelin J, Arganda-Carreras I, Frise E, Kaynig V, Longair M, Pietzsch T, et al. Fiji: an open-source platform for biological-image analysis. Nat Methods. 2012;9:676

38. Petrášek J, Černá A, Schwarzerová K, Elčkner M, Morris DA, Zazimalova E. Do phytotropins inhibit auxin efflux by impairing vesicle traffic? Plant Physiol. 2003;131:254-63.

39. Rubery P, Sheldrake A. Carrier-mediated auxin transport. Planta. 1974;118(2): $101-21$

40. Teale W, Palme K. Naphthylphthalamic acid and the mechanism of polar auxin transport. J Exp Bot. 2017:69:303-12.

41. Radotić K, Roduit C, Simonović J, Hornitschek P, Fankhauser C, Mutavdžić D, et al. Atomic force microscopy stiffness tomography on living Arabidopsis thaliana cells reveals the mechanical properties of surface and deep cellwall layers during growth. Biophys J. 2012;103:386-94.

42. Feraru E, Feraru Ml, Kleine-Vehn J, Martiniere A, Mouille G, Vanneste S, et al. PIN polarity maintenance by the cell wall in Arabidopsis. Curr Biol. 2011;21:338-43.

43. Tolmie F, Poulet A, McKenna J, Sassmann S, Graumann K, Deeks M, et al. The cell wall of Arabidopsis thaliana influences actin network dynamics. J Exp Bot. 2017:68:4517-27.

44. Hu XY, Neill SJ, Cai WM, Tang ZC. Induction of defence gene expression by oligogalacturonic acid requires increases in both cytosolic calcium and hydrogen peroxide in Arabidopsis thaliana. Cell Res. 2004;14:234-40. 
45. Garcia-Brugger A, Lamotte $\mathrm{O}$, Vandelle E, Bourque S, Lecourieux D, Poinssot $B$, et al. Early signaling events induced by elicitors of plant defenses. Mol Plant-Microbe Interact. 2006;19:711-24.

46. Link VL, Hofmann MG, Sinha AK, Ehness R, Strnad M, Roitsch T. Biochemica evidence for the activation of distinct subsets of mitogen-activated protein kinases by voltage and defense-related stimuli. Plant Physiol. 2002;128:271-81.

47. Kurusu T, Kuchitsu K, Nakano M, Nakayama Y, lida H. Plant mechanosensing and $\mathrm{Ca}^{2+}$ transport. Trends Plant Sci. 2013;18:227-33.

48. Reddy AS. Calcium: silver bullet in signaling. Plant Sci. 2001;160:381-404.

49. White PJ, Broadley MR. Calcium in plants. Ann Bot. 2003;92:487-511.

50. Ma W, Berkowitz GA. The grateful dead: calcium and cell death in plant innate immunity. Cell Microbiol. 2007:9:2571-85.

51. Seifertová D, Skůpa P, Rychtář J, Laňková M, Pařezová M, Dobrev PI, et al. Characterization of transmembrane auxin transport in Arabidopsis suspension-cultured cells. J Plant Physiol. 2014;171:429-37.

52. Delbarre A, Muller P, Imhoff V, Guern J. Comparison of mechanisms controlling uptake and accumulation of 2, 4-dichlorophenoxy acetic acid, naphthalene-1-acetic acid, and indole-3-acetic acid in suspension-cultured tobacco cells. Planta. 1996;198:532-41.

53. Campanoni P, Blasius B, Nick P. Auxin transport synchronizes the pattern of cell division in a tobacco cell line. Plant Physiol. 2003;133:1251-60.

54. Keller CP, Stahlberg R, Barkawi LS, Cohen JD. Long-term inhibition by auxin of leaf blade expansion in bean and Arabidopsis. Plant Physiol. 2004;134:1217-26.

55. Petrášek J, Zažímalová E. The BY-2 cell line as a tool to study auxin transport. In: Tobacco BY-2 cells: from cellular dynamics to omics. Berlin: Springer; 2006. p. 107-17.

56. Hu W, Fagundez S, Katin-Grazzini L, Li Y, Li W, Chen Y, Wang X, Deng Z, Xie $S, M c A v o y$ RJ. Endogenous auxin and its manipulation influence in vitro shoot organogenesis of citrus epicotyl explants. Hortic Res. 2017:4:17071.

57. Zhang J, Peer WA. Auxin homeostasis: the DAO of catabolism. J Exp Bot 2017:68:3145-54.

58. Larsson E, Sitbon F, von Arnold S. Polar auxin transport controls suspensor fate. Plant Signal Behav. 2008;3:469-70.

59. Hong JH, Savina M, Du J, Devendran A, Ramakanth KK, Tian X, et al. A sacrifice-for-survival mechanism protects root stem cell niche from chilling stress. Cell. 2017:170:102-13.

60. Perrot-Rechenmann C. Cellular responses to auxin: division versus expansion. Cold Spring Harb Perspect Biol. 2010;2:a001446.

61. Majda M, Robert $\mathrm{S}$. The role of auxin in cell wall expansion. Int J Mol Sci. 2018;19(4):951.

62. Nafisi M, Fimognari L, Sakuragi Y. Interplays between the cell wall and phytohormones in interaction between plants and necrotrophic pathogens. Phytochemistry. 2015;112:63-71.

63. Braybrook SA, Peaucelle A. Mechano-chemical aspects of organ formation in Arabidopsis thaliana: the relationship between auxin and pectin. PLoS One. 2013:8:e57813.

64. Dünser K, Kleine-Vehn J. Differential growth regulation in plants - the acid growth balloon theory. Curr Opin Plant Biol. 2015;28:55-9.

65. Barbez E, Dünser K, Gaidora A, Lendl T, Busch W. Auxin steers root cell expansion via apoplastic $\mathrm{pH}$ regulation in Arabidopsis thaliana. Proc Natl Acad Sci U S A. 2017;114:E4884-93.

66. Feraru E, Friml J. PIN Polar Targeting. Plant Physiol. 2008;147:1553-9.

67. Lehman TA, Smertenko A, Sanguinet KA. Auxin, microtubules, and vesicle trafficking: conspirators behind the cell wall. J Exp Bot. 2017;68:3321-9.

68. Paciorek T, Zažímalová E, Ruthardt N, Petrášek J, Stierhof Y-D, Kleine-Vehn J, et al. Auxin inhibits endocytosis and promotes its own efflux from cells. Nature. 2005:435:1251-6.

69. Sauer M, Balla J, Luschnig C, Wiśniewska J, Reinöhl V, Friml J, et al. Canalization of auxin flow by aux/IAA-ARF-dependent feedback regulation of PIN polarity. Genes Dev. 2006;20:2902-11.

70. Vieten A, Vanneste S, Wiśniewska J, Benková E, Benjamins R, Beeckman $T$, et al. Functional redundancy of PIN proteins is accompanied by auxin-dependent cross-regulation of PIN expression. Development. 2005;132:4521-31.

71. Kleine-Vehn J, Dhonukshe P, Sauer M, Brewer PB, Wiśniewska J, Paciorek T, et al. ARF GEF-dependent transcytosis and polar delivery of PIN auxin carriers in Arabidopsis. Curr Biol. 2008;18:526-31.

72. Smertenko A, Franklin-Tong VE. Organisation and regulation of the cytoskeleton in plant programmed cell death. Cell Death Differ. 2011; 18(8):1263-70.

73. Nick P. Probing the actin-auxin oscillator. Plant Signal Behav. 2010;5:94-8.
74. Nick P, Han MJ, An G. Auxin stimulates its own transport by shaping actin filaments. Plant Physiol. 2009;151:155-67.

75. Chang X, Riemann M, Liu Q, Nick P. Actin as deathly switch? How auxin can suppress cell-death related defence. PLoS One. 2015;10(5):e0125498.

76. Hutter JL, Bechhoefer J. Calibration of atomic-force microscope tips. Rev Sci Instrum. 1993;64:1868-73.

\section{Publisher's Note}

Springer Nature remains neutral with regard to jurisdictional claims in published maps and institutional affiliations.
Ready to submit your research? Choose BMC and benefit from:

- fast, convenient online submission

- thorough peer review by experienced researchers in your field

- rapid publication on acceptance

- support for research data, including large and complex data types

- gold Open Access which fosters wider collaboration and increased citations

- maximum visibility for your research: over $100 \mathrm{M}$ website views per year

At BMC, research is always in progress.

Learn more biomedcentral.com/submissions 